\title{
THE INFLUENCE OF ONLINE CAMBRIDGE DICTIONARY TOWARD STUDENTS' PRONUNCIATION AND VOCABULARY MASTERY
}

\author{
Rosita Ambarwati ${ }^{1}$, Berlinda Mandasari ${ }^{2}$ \\ Universitas Teknokrat Indonesia
}

rositaambar98@gmail.com ${ }^{1}$, berlinda@teknokrat.ac.id²

\begin{tabular}{lll}
\hline Received: 30 October 2020 & Accepted: 15 December 2020 & Published: 30 December 2020 \\
\hline
\end{tabular}

\begin{abstract}
Dictionary has become one important tool for learning a foreign language. Many kinds of dictionaries can be used for students who want to learn a foreign language. An online dictionary is one of the technologies that can be used for learning a foreign language. Nowadays in the digital era, students can use it through internet networking. Thus, this study discusses the influence of the online Cambridge dictionary on students' pronunciation and vocabulary of students at Universitas Teknokrat Indonesia (UTI). Subjects of the research were 25 students who take Academic Writing subject majoring in English Education study program. Data were then analyzed by using descriptive analysis. Data were collected through questionnaires and interviews, the student was given a questionnaire and interview related to an alternative reference in technology for learning vocabulary and pronunciation especially online Cambridge dictionary. As a result of this study, the online Cambridge dictionary influences student pronunciation and vocabulary in terms of pronunciation mastery and vocabulary enrichment. It is suggested that the online Cambridge dictionary can be an alternative solution to solve the problem of pronunciation and vocabulary mastery.
\end{abstract}

Keywords: vocabulary. Online Cambridge Dictionary, pronunciation.

\section{To cite this article:}

Ambarwati, R. \& Mandasari, B. (2020). The Influence of Online Cambridge Dictionary on Students' Pronunciation and Vocabulary Mastery. Journal of English Language Teaching and Learning, 1(2), 50-55.

\section{INTRODUCTION}

In a millennial era, many students or people use English, when they are at school or home for daily communication. In Indonesia learning is considered a foreign language since is not spoken in daily communication. However, the Indonesian government obligates Indonesian students to learn English started from elementary school until senior high school. In the digital era, technology is an important tool for students to master language learning by maximizing digital media and the use of internet (Sari, 2020). Utilizing technology in language learning can help students improve their academic performance (Mandasari, 2020) and help them to focus on the material although it discusses abstract things (Oktaviani \& Desiarti, 2017). Besides, it also gives two advantages: 1) learning strategies and 2) improves students' understanding in using technology as a learning medium (Oktaviani \& Mandasari, 2020). As stated by Aminatun and Oktaviani (2019), the development of technology provides various learning strategies that are suitable to make students become independent learners. As it occurs in college students, strategies are used to support the learning process (Putri \& Sari, 2020).

One technology that helps the lecturer to support teaching pronunciation and vocabulary mastery is an online dictionary. According to Hartmann \& James (2001), an online dictionary is a dictionary or other reference work available via a computer network such as the internet. As language learners, students only need to use their gadgets which are connected to the internet to use the online dictionaries. It means that an online dictionary can be an important tool for students in learning a foreign language to offer easiness and effectiveness to make students easily when learning the English language.

Learning the English language must have some skills, namely listening, writing, reading, and speaking. According to Haris (1969), five components are supported by language elements such as structure/grammar, vocabulary, pronunciation, fluency, and comprehension. The study from Harmer (2002) reveals that the important elements of learning English are pronunciation and vocabulary, and it is a major core in studying a foreign language. As stated by the Adult Migrant English Program (2001), pronunciation is how a language is spoken and 
pronounced. That language and the pronunciation of each language is mostly a physical phenomenon stated by Cameron (2012). The reason students must have a good way to pronounce a word when they want to be a good speaker if the students can't pronounce words in a good way it can make people difficult to understand or even misunderstanding. Moreover, the statement from Nikolov (2009) tells that vocabulary is one of the elements that contribute to every level of communication and comprehension in the target language. It means that vocabulary is very influential to English learners, it can be considered as the basis for being able to communicate through spoken or written interaction. Furthermore, according to Scott (2002) without grammar, very little in communication can be conveyed, but without vocabulary, nothing can be conveyed. Moreover, if the students want to be good speakers the students must have a lot of vocabulary. A study conducted by Huyen \& Nga (2003) stated that vocabulary plays an important role in learners in learning a foreign language. Vocabulary is all about words, the words in a language or a special set of words students trying to learn. So, in this study, the use of a dictionary is a very important tool.

Why do we use a dictionary when learning the English language? Seeing the importance of vocabulary enrichment and pronunciation mastery, it is necessary to teach a learning strategy that emphasizes the use of dictionaries. There are various kinds of dictionaries one of them is the online Cambridge dictionary. The Online Cambridge dictionary is the dictionary that contains definitions and audio pronunciations of words, phrases, and idioms in British and American English style. The benefits of using this online dictionary are the students can improve their pronunciation ability through hearing the sound and also the students can pronounce words in a better way because the online Cambridge dictionary is a typical representative of specialized pronunciation dictionaries, Roach, Setter, Esing (2011). Moreover, the online Cambridge dictionary also has the functions of vocabulary enrichment and understand the variations of the words, which means that the online Cambridge dictionary works well for students learning tool. According to Metruk (2016), Cambridge advanced learner dictionary, to be a popular dictionary among EFL students or learners. So, this study will find out the effect of the online Cambridge dictionary on the pronunciation and vocabulary mastery of students at UniversitasTeknokrat Indonesia majoring in English Education.

\section{METHOD}

This research article applied a qualitative study in which the data were analyzed by using descriptive analysis. According to Bodgan \& Biklen (2003), descriptive is the characteristic of data in qualitative research as it is taken from documents, audio-video recordings, transcripts, words, pictures, etc. participants of this mini research were some students chosen randomly from Academic Writing subject majoring English Education study program in Universitas Teknokrat Indonesia (UTI). Due to limited time, the researcher focused only on 25 participants. Students of English education study programs were chosen by the researchers because they learn the English language for their material. This research focused on the influence of the online Cambridge dictionary on student pronunciation and vocabulary. The research instruments used by the researchers were questionnaires and interviews. According to Johnson \& Christensen (2012) questionnaire is a self-report data collection instrument that each research participant fills out as part of a research study. The researcher used a questionnaire and interview to obtain information about the thoughts, feeling, attitudes, beliefs, values, perceptions, personality, and behavioral intentions of the research participants.

In this part, the researcher used Dichotomous Questions which consist of 10 questions, and the Likert Scale which consists of 10 closed-ended statements about the influence of the online Cambridge dictionary toward the student pronunciation and vocabulary. The questionnaire has several scores for each answer. The Dichotomous Questions with a simple answer "yes" or "no" and the Likert Scale's scores are one for Strongly Agree, Agree, Disagree, and Strongly Disagree. Besides using the questionnaire, the researchers using the interview to strengthen the findings, an open-ended interview was conducted to explore their respond and perspective toward the online Cambridge dictionary. The interview data were transcribed into words to find out the result. To know the influence of using an online Cambridge dictionary on student pronunciation and vocabulary, questionnaires and interviews were conducted in a writing class (PBI 17 students) Universitas Teknokrat Indonesia. This questionnaire and interview were conducted on 5-6 December 2019.

To gain data about the influence of the online Cambridge dictionary on student pronunciation and vocabulary, the researcher collected the data through questionnaires and interviews. The questionnaire contains statements about their perception of using the online Cambridge dictionary. The students were given a questionnaire in the middle of the semester.

Data obtained through questionnaire were analyzed by finding out the mean score and percentage of the score. Data from English Education student batch 17 were presented in tables. Those data were then compared. The interpretation of the mean score and percentage score was seen from the evaluation criteria of the questionnaire. Furthermore, data through interviews were analyzed by finding out the transcription. 


\section{FINDINGS AND DISCUSSION}

In this section, the findings and discussion to answers the research questions are presented. After implementing the research, the researcher found some data. The data consist of the questionnaire results. At first, the students of writing class responses taken from the questionnaire consist of twenty closed-ended questions and statements. After implementing the research, the researcher gets the result for the Dichotomous questions section as below:

Table 1. Student's Opinions toward Online Cambridge Dictionary Usage

\begin{tabular}{lcc}
\hline \multicolumn{1}{c}{ Questions } & "Yes" (\%) & "No" (\%) \\
\hline Can you live without the internet? & $12 \%$ & $88 \%$ \\
Did you ever use an online dictionary? & $100 \%$ & $0 \%$ \\
Do you like an online dictionary? & $100 \%$ & $0 \%$ \\
Do you have an online dictionary on your phone? & $96 \%$ & $4 \%$ \\
Do you know what the online Cambridge dictionary is? & $100 \%$ & $0 \%$ \\
Did you ever use an online Cambridge dictionary? & $92 \%$ & $8 \%$ \\
Do you often use the online Cambridge dictionary? & $80 \%$ & $20 \%$ \\
Are you familiar with the Cambridge dictionary application? & $88 \%$ & $12 \%$ \\
Do you like the online Cambridge dictionary? & $92 \%$ & $8 \%$ \\
Does the online Cambridge dictionary that you used help you in learning & $100 \%$ & $0 \%$ \\
the English language? & & $\mathbf{8 6 \%}$ \\
\hline \multicolumn{2}{c}{ Mean }
\end{tabular}

From the table above, it can be seen from the first question there were $12 \%$ of students could live without internet it means that almost all students couldn't live without internet with the percentage of $88 \%$. The statement from Shahroom \& Hussin (2018) said that to face IR 4.0 university students must have technology improvement as a foundation. So, to support their learning process students usually use the internet as their learning tool through laptop or phone to open any kind of website or application. Furthermore, the second question there were $100 \%$ of students answer ever use an online dictionary. Metruk (2017) explain that using a dictionary for EFL students has become an inseparable and indispensable tool for learning a foreign language. So, in this digital era creation of electronic dictionaries makes readily and easily available to EFL students. For the next questions, same with the previous question there were $100 \%$ of student answer that they like online dictionary it means that all of the students like these tools to support in learning EFL. Next, there were $96 \%$ of students have an online dictionary in their phone, which means only 1 participant or student don't have an online dictionary in their gadget, it shows that they need an online dictionary to check the new words.

Furthermore, related to the online Cambridge dictionary, there were $100 \%$ of students know what the online Cambridge dictionary is, which means all of the students know this application. Zykova (2008) stated that specialized dictionaries concern the lexical unit only concerning some of their features, such as pronunciation, usage, frequency, and etymology. Roach, Setter, \& Esling (2011) stated that pronunciation is concerned Cambridge English pronouncing dictionaries. Next, there were $92 \%$ of students ever used this application, to master pronunciation and vocabulary enrichment students must have this application, from this electronic dictionary it can be a useful tool for EFL learner. "An electronic dictionary has the potential to provide an instant access from within a given entry to a key to the symbols used in the relevant phonological transcription and also, at the click of a button, to model the pronunciation of any given word in audio mode" Singleton, (2016). From question number 7 , it can be seen that there were $80 \%$ of students often use this online Cambridge dictionary. It shows that $20 \%$ of students not often use this application, because sometimes the students use Google translate as an alternative dictionary.

However, there were $88 \%$ of students familiar with this online Cambridge dictionary. The reason why students familiar with this application is when the respondents in vocabulary class $\left(2^{\text {nd }}\right.$ semester) the respondents often used this application or online Cambridge dictionary to know how to pronounce the word in a good way and the meaning of that word so it can make the respondents familiar with this electronic dictionary. Furthermore, $92 \%$ of students like this online Cambridge dictionary (electronic dictionary). It means almost of the respondent claimed that the online Cambridge dictionary helped the students to support learning process especially when they want to know how to pronounce word well and to know the meaning of those words. For the last, all the students answer that electronic dictionaries help them when learning EFL. There were 100\% of students answering "yes" to those questions. Several studies have been carried out regarding electronic dictionaries. Alfallaj (2013) stated that an electronic dictionary is one of the media which help students, not only to enrich vocabulary but also for pronunciation. Finally, the mean of this questionnaire there were 82, which means almost all the students gave positive opinions or impact about the online Cambridge dictionary usage.

To strengthen the findings of the research, the students were interviewed for several questions related to their experiences using the online Cambridge dictionary (electronic dictionary). From the interview, it was found 
Journal of English Language Teaching and Learning (JELTL), Vol. 1, No. 2, 50-55

out that most students discovered several advantages using electronic dictionaries especially online Cambridge dictionaries. It can be seen in the student responses in the interview.

Student 1: "Yes, because I never left my cellphone, I use my cellphone to help me to do my assignment. I have used the online Cambridge dictionary application at the time of the pronunciation course in semester 2. I also often use this application to find out the correct pronunciation of words and also see phonetic transcription during phonology courses."

Student 2: "Yes I do. I have used the online Cambridge dictionary application when I wanted to check the correct way of pronouncing words during speaking class, because usually during a presentation I forget how to pronounce words that I think are less familiar. So, this online dictionary helps me to do my task."

After implementing the research, the researcher gets the result for the Likert scale/statements section as below:

Table 2. Student's Responses on Using Online Cambridge Dictionary toward Pronunciation Mastery

\begin{tabular}{|c|c|c|c|c|c|}
\hline No & Statements & $\begin{array}{c}\text { Strongly } \\
\text { Agree (\%) }\end{array}$ & $\begin{array}{c}\text { Agree } \\
(\%)\end{array}$ & $\begin{array}{l}\text { Disagree } \\
(\%)\end{array}$ & $\begin{array}{c}\text { Strongly } \\
\text { Disagree } \\
(\%)\end{array}$ \\
\hline 1 & $\begin{array}{l}\text { I like the online Cambridge dictionary as a reference } \\
\text { for learning English. }\end{array}$ & $20 \%$ & $48 \%$ & $12 \%$ & $20 \%$ \\
\hline 2 & $\begin{array}{l}\text { Online Cambridge dictionary can influence my } \\
\text { pronunciation skill in a better way. }\end{array}$ & $20 \%$ & $60 \%$ & $12 \%$ & $8 \%$ \\
\hline 3 & $\begin{array}{l}\text { Online Cambridge dictionary can improve my } \\
\text { pronunciation through hear the sound of the word. }\end{array}$ & $20 \%$ & $48 \%$ & $20 \%$ & $12 \%$ \\
\hline 4 & $\begin{array}{l}\text { I can pronounce words easily after learning with the } \\
\text { online Cambridge dictionary. }\end{array}$ & $40 \%$ & $40 \%$ & $10 \%$ & $10 \%$ \\
\hline 5 & $\begin{array}{l}\text { The Online Cambridge dictionary is an effective tool } \\
\text { to improve my pronunciation skill. }\end{array}$ & $20 \%$ & $60 \%$ & $20 \%$ & $0 \%$ \\
\hline
\end{tabular}

From the table above, it could be seen that the students showing positive responses by loving it in presentation $68 \%$ (48\% of students agreed and $20 \%$ strongly agreed) it means students like the online Cambridge dictionary as a reference in learning English it shows more than $60 \%$ of students agreed or like this dictionary. According to Metruk (2016), the electronics dictionary like Cambridge Advanced Learner's Dictionary (2013) seem to be rather a popular tool among EFL learner. It means that people in this era like to use this online dictionary. It was also in the second question that the online Cambridge dictionary can influence student pronunciation ability in a better way. There were $60 \%$ of students who agreed and $20 \%$ of students strongly agreed about the second question. Furthermore, the statement from Singleton (2006) tells that an electronic or online dictionary provides the symbol used in the relevant phonological transcription and also audio mode. So, the students also agreed that an online Cambridge dictionary can increase their pronunciation through hearing the sound of the word because it shows $48 \%$ of students agreed and $20 \%$ of students strongly agreed. After the students hear the sounds through an online Cambridge dictionary students can produce sounds correctly, the statement from Indriani (2001) explains the ability to produce sounds by using certain of the body's mechanism. To begin with, people produce sounds using parts of their chest, throat, and head (Roach, 2001). Furthermore, in the next statements, there were $40 \%$ of students strongly agreed and $40 \%$ of students agreed, it means more than $80 \%$ of students agree that after using the online Cambridge dictionary they can pronounce word easily. For the last, there were more than $70 \%$ of students agreed that the online Cambridge dictionary is an effective tool for EFL learners.

Table 3. Student's Responses using Online Cambridge Dictionary toward Vocabulary Enrichment

\begin{tabular}{|c|c|c|c|c|c|}
\hline No & Statements & $\begin{array}{c}\text { Strongly } \\
\text { Agree }(\%)\end{array}$ & $\begin{array}{l}\text { Agree } \\
(\%)\end{array}$ & $\begin{array}{l}\text { Disagree } \\
\quad(\%)\end{array}$ & $\begin{array}{c}\text { Strongly } \\
\text { Disagree } \\
(\%)\end{array}$ \\
\hline 1 & $\begin{array}{l}\text { I can enrich my vocabulary by using the Online } \\
\text { Cambridge dictionary. }\end{array}$ & $20 \%$ & $48 \%$ & $20 \%$ & $12 \%$ \\
\hline 2 & $\begin{array}{l}\text { I can memorize new words easily after studying using } \\
\text { the Online Cambridge dictionary. }\end{array}$ & $24 \%$ & $40 \%$ & $12 \%$ & $24 \%$ \\
\hline 3 & $\begin{array}{l}\text { I get a lot of new vocabulary after studying using the } \\
\text { online Cambridge dictionary. }\end{array}$ & $68 \%$ & $22 \%$ & $10 \%$ & $0 \%$ \\
\hline
\end{tabular}




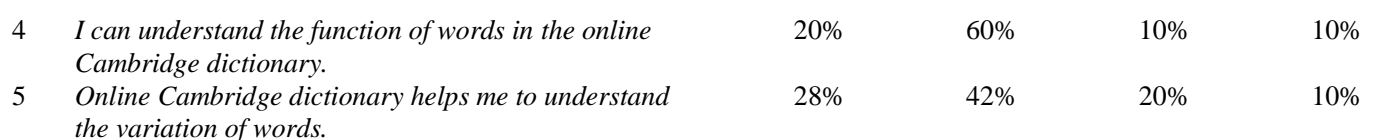

From the table above, it could be seen that $48 \%$ of students agreed and $20 \%$ of students strongly agreed that online Cambridge dictionary can enrich their vocabulary, it means that more than $60 \%$ of students agreed because from vocabulary students can translate the new words. According to Dale and O'Rouke (1971), mastering vocabulary means knowing, understanding, and being able to use it. It means that students do not only memorize words and understand the meanings but also be able to apply them. Vocabulary is important for language learners because it is the first step that they have to take in learning a new language. From this research got the result that from Cambridge dictionary students can enrich their vocabulary. Next statements, there were $40 \%$ of students agreed and $24 \%$ of students strongly agreed that using the online Cambridge dictionary means that more than $60 \%$ of students agreed that the online Cambridge dictionary can help the students to memorize the new words easier. Moreover, students not only can memorize words easily but also get a lot of new vocabulary after studying using the online Cambridge dictionary, because there were more than $80 \%$ of students agreed if these statements. Then, $60 \%$ of students agreed and $20 \%$ of students strongly agreed that from an online Cambridge dictionary they can understand the function of words themselves. For the last statements, it shows there were $42 \%$ of students agreed and $28 \%$ of students strongly agreed that the online Cambridge dictionary helps students to understand the variation of words.

From the findings and discussions above the researchers conclude that online Cambridge dictionaries can influence student pronunciation mastery and vocabulary enrichment. Online dictionaries become more interesting a printed dictionary, behind the good impacts that students felt after using the online dictionary, they realized that everything is good under control. It means that using the online dictionary is helpful and effective. However, as good learners, they have to be able to use technology wisely.

\section{CONCLUSION}

This section presents the conclusion of the research. The process of the research took about 3 weeks, from 22 November 2019. In conclusion, the online Cambridge dictionary website/application helped the students when they are trying to learn how to pronounce words well, and when students want to enrich their vocabulary. The Online Cambridge dictionary offers easiness and effectiveness that it can be used easily by all language learners. By using the online Cambridge dictionary, students are easier learning English especially in phonology and vocabulary subjects and students appreciate the easiness and effectiveness.

\section{REFERENCES}

Adult Migrant English Program. (2001). Fact Sheet-What Is Pronunciation?. Research Centre, p.01 at www.amepre.mq.edu.au/docs/fact_sheets/01

Alfallaj, F. (2013). The Use of Linguistics in Teaching Pronunciation to Saudi Students. SUST Journal of Humanities, 14(2), 134-143.

Aminatun, D. \& Oktaviani, L. (2019). Memrise: Promoting Students’ Autonomous Learning Skill through Language Learning Application. Metathesis: Journal of English Language Literature and Teaching, 3(2), 214-223.

Bogdan, R.C., \& Biklen, S. K. 2003. Qualitative Research for Education: An Introduction to Theories and Method (4th Ed.). New York: Pearson.

Cameron, S. (2012). Perfecting Your English Pronunciation. New York City: McGraw Hill.

Dale, E., \& O’Rouke, J. (1971). Techniques of Teaching Vocabulary. San Francisco: The Benjamin/Cummings Publ. co.

Harris, David, P. (1969). Testing English as Second Language. New York: McGraw Hill Company, p.83.

Hartman, R.R.K., \& James, G. (2001). Dictionary of Lexicography. New York: Routledge.

Huyen, N. T. T., \& Nga, K.T.T. (2003). Learning Vocabulary through Games. Vietnamese: ASIAN EFL Journal.

Indriani, M. I. (2001). English pronunciation: The English Speech Sounds Theory \& Practice. Jakarta: Gramedia Pustaka Utama.

Jeremy, H. (2002). The Practice of English Language Teaching. New York: Longman.

Johnson, B., \& Christensen, L. (2012). Educational Research 4th Edition. New York: Sage Publications, Inc.

Mandasari, B. (2020). The Impact of Online Learning on Students' Academic Performance on Business Correspondence Course. EDUTEC: Journal of Education and Technology, 4(1), 98-110.

Metruk, R. (2016). Determining The Priority in Vocabulary When Learning English through Electronic Dictionaries. Xlinguae - European scientific language journal, 9(4), 2-8.

Metruk, R. (2017). The Use of Electronic Dictionaries for Pronunciation Practice by University EFL Students. The University of Žilina.Univerzitná 8215/1, 01026 Žilina, Slovakia.

Nikolov, Marianne. (2009). Early Learning of Modern Foreign Languages. Salisbury: Short Run Press. 
Journal of English Language Teaching and Learning (JELTL), Vol. 1, No. 2, 50-55

Oktaviani, L. \& Desiarti, E. (2017). A Lecturer's and Students' Perspective toward Ethnic Snake Game in Speaking Class at Universitas Muhammadiyah Malang. Teknosastik: Journal Bahasa dan Sastra. 15(2), 53-59. DOI: https://doi.org/10.33365/ts.v15i2.98

Oktaviani, L. \& Mandasari, B. (2020). Powtoon: A Digital Medium to Optimize Students' Cultural Presentation in ELT Classroom. Teknosastik: Jurnal Bahasa dan Sastra, 18(1), 33-41. DOI: https://doi.org/10.33365/ts.v18i1.526

Putri, E. \& Sari, F. M. (2020). Indonesian EFL Students' Perspectives towards Learning Management System Software. Journal of English Language Teaching and Learning, 1(1), 20-24.

Roach, Peter. (2001). Phonetics. New York: Oxford University Press.

Roach, P., Setter, J., \& Esling, J. (Eds.). (2011). Cambridge English Pronouncing Dictionary (18th Ed.). Cambridge: Cambridge University Press.

Sari, F. M. (2020). Exploring English Learners' Engagement and Their Roles in the Online Language Course. Journal of English Language Teaching and Linguistics, 5(3), 349-361.

Singleton, D. (2016). Language and the Lexicon.an Introduction. New York: Routledge.

Shahroom, A.A. \&Hussin, N. 2018. Industrial Revolution 4.0 and Education. International Journal of Academic Research in Business and Social Sciences, 8(9), 314-319.

Thornbury.Scot. (2002). How to Teach Vocabulary. Harlow: Pearson.

Zykova, I. V. A. (2008). A Practical Course in English Lexicology. Moscow: Akademiya.

\section{BIOGRAPHY OF AUTHORS}

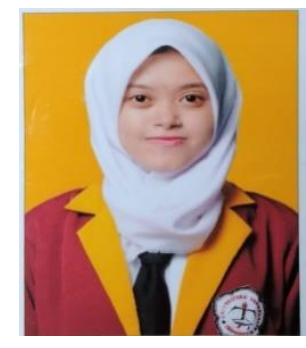

Rosita Ambarwati is an active student in the English Education Study Program, Faculty of Arts and Education, Universitas Teknokrat Indonesia. During her study, she actively joins in students' organization.

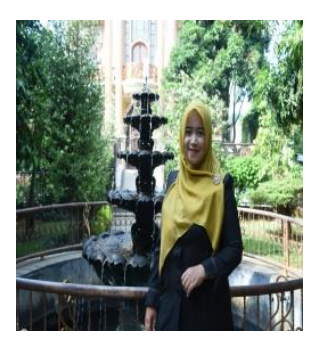

Berlinda Mandasari is an English education lecturer at Universitas Teknokrat Indonesia. Her research interest focuses on teaching English as a Foreign language, Language Assessment, and teaching media. She has ever been awarded research Grants in 2018 and 2019 from the Ministry of Research, Technology, and Higher Education for the program of Penelitian Dosen Pemula (PDP). Now, she is working on the research on Blended Learning as well as accomplishing a handbook of Preintermediate grammar to publish. 